\title{
Potato genotypes and environments under potato in the Brazilian Cerrado biome
}

\section{Aniela Pilar Campos de Melo ${ }^{*}$ (D) Paulo Marçal Fernandes ${ }^{2}$ (D) Carlos de Melo e Silva-Neto ${ }^{3}$ (D) Eli Regina Barboza de Souza $^{2}$ (D) Ariane Carla Campos de Melo ${ }^{4}$ (D) Alexsander Seleguini ${ }^{5}$ (D)}

\author{
${ }^{1}$ Instituto Federal Goiano (IFGoiano), 73.850-000, Cristalina, GO, Brasil. E-mail: aniela.pcdmelo@gmail.com. "Corresponding author. \\ ${ }^{2}$ Universidade Federal de Goiás (UFG), Goiânia, GO, Brasil. \\ ${ }^{3}$ Instituto Federal de Goiás (IFG), Cidade de Goiás, GO, Brasil. \\ ${ }^{4}$ Universidade de São Paulo (USP), São Paulo, SP, Brasil. \\ ${ }^{5}$ Universidade Federal do Triângulo Mineiro (UFTM), Iturama, MG, Brasil.
}

\begin{abstract}
The objective was to estimate the physiological and productive performance of potato genotypes in two organic cultivation systems. Two trials were conducted, being one in a protected and on in an open-field environment. A randomized complete block design with four replicates and five treatments (genotypes 'Agata', 'Atlantic', 'BRS Ana', 'BRSIPR Bel'and 'BRS Clara') was used. Physiological, productive characteristics and defects associated with tubers were obtained. The protected environment is the most appropriate to produce organic potatoes under the evaluated conditions. Genotypes 'BRSIPR Bel' and 'BRS Ana' exhibit a high productive potential in organic conditions.
\end{abstract}

Key words: Solanum tuberosum, alternative agriculture, stems, performance, tubers.

Genótipos de batata e ambientes em sistema orgânico de produção no bioma Cerrado Brasileiro

RESUMO: Objetivou-se estimar o desempenho fisiológico e produtivo de genótipos de batata em dois ambientes de cultivo em sistema orgânico. Foram conduzidos dois ensaios, sendo um em condições de ambiente protegido e outro em campo aberto. Empregou-se o delineamento em blocos completos casualizados com quatro repetições e cinco tratamentos referentes aos genótipos 'Agata', 'Atlantic', 'BRS Ana', 'BRSIPR Bel'e 'BRS Clara'. Avaliaram-se atributos fisiológicos, produtivos e defeitos associados aos tubérculos. O ambiente protegido é o mais adequado para a produção de batata orgânica nas condições avaliadas. Os genótipos 'BRSIPR Bel'e 'BRS Ana' possuem alto potencial produtivo em condições de sistema orgânico.

Palavras-chave: Solanum tuberosum, agricultura alternativa, hastes, desempenho, tubérculos.

\section{INTRODUCTION}

The worldwide potato production comes mostly from the Northern hemisphere (FAOSTAT, 2021), in open-field conditions. Cultivation in protected environment is only recommended to multiply seed tubers in the acclimatization phase, and for pre-basic seed potatoes multiplication (aeroponics) (ÇALIŞKAN et al., 2020).

Conventional potato cultivation is a highrisk investment regarding economic viability. In Brazil, production cost ranges from 5600 to 8800 dollars per hectare (CEPEA-ESALQ, 2020). Therefore, a relevant income is only obtained in large areas, with high production volume. In this context, migrating the potato production to a protected environment is unlikely due to the high costs of greenhouses and high investment in each cycle. However, it may be a good option for organic production.

Areas destined for potato production in an organic system are usually small. The productivity is overall low mainly due to nutritional and phytosanitary issues (BUSNELLO et al., 2019). In such conditions the protected environment may favor pest, disease and nutrient management. In addition, there is a growing demand for organic potatoes in the market (GREENWAY et al., 2011). However, it is know, there are few information describing the technical viability of potato cultivation in protected environments for commercial purposes. Thus, the objective of this study was to estimate the physiological and productive performance of potato genotypes in two environments in organic cultivation systems.

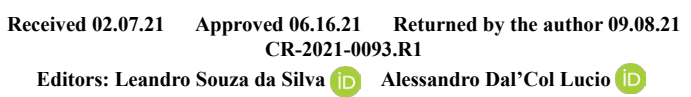




\section{MATERIALS AND METHODS}

Two trials were conducted - one in a protected and one in an open-field environment. Both trials were conducted in organic systems consolidated for 14 years, at Hidrolândia, Goiás, Brazil (1657'51.79” S; 49¹1'02.09” W; $865 \mathrm{~m}$ altitude). The climate of the region, according to Koppen, is characterized by rainy summer and dry winter.

The protected environment trial was conducted in a greenhouse $(14 \times 50 \mathrm{~m})$. Before the potato cultivation was implemented, the area was managed for tomato cultivation followed by beans and fallow. The soil is an Oxisol and has the following physical-chemical attributes: texture (Clay 31\%, Silt $8 \%$, Sand $61 \%)$, pH (6.1), organic matter (24\%), CEC (8.38), base saturation (80.85\%), K (59 ppm), Ca (5.3

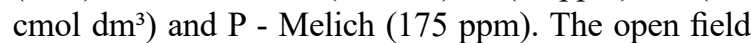
trial was conducted on an Oxisol with the following physical-chemical attributes: Texture (Clay 35\%, Silt $10 \%$, Sand 55\%), pH (6.5), Organic matter (28\%), CEC $(8,52)$, base saturation $(85.91 \%), \mathrm{K}(244 \mathrm{ppm})$, $\mathrm{Ca}\left(4.90 \mathrm{cmol} \mathrm{dm}^{3}\right)$ and P-Melich (132 ppm). The open field area was managed with tomato, corn and fallow before the establishment of the potato cultivation.

A randomized complete block design with four replicates and five treatments (genotypes 'Agata', 'Atlantic', 'BRS Ana', 'BRSIPR Bel' and 'BRS Clara') was used. 'Agata' and 'BRS Clara' tubers are suitable for cooking, while 'Atlantic' and 'BRSIPR Bel' are suitable for frying. 'BRS Ana' suits both cooking and frying.

The plot consisted on a 10 -meter line. The seed tubers were planted in a $1 \mathrm{~m}$ spacing between rows and $0.33 \mathrm{~m}$ spacing within rows. The planting took place on April, a date defined based on defined the astronomical calendar. The diameter of the 'Agata' and 'Atlantic' seed tubers ranged from 20 to $25 \mathrm{~mm}$, and of 'BRS Ana', 'BRSIPR Bel' and 'BRS Clara' from 30 to $50 \mathrm{~mm}$. Fertilization took place in the furrow using chicken manure (one kilo per meter) and earthworm humus (one kilo per meter). No cover fertilizer was used.

Drip irrigation was performed in both trials (five liters of water per meter - irrigation frequency: every 48 hours), and no pest or disease management was implemented. The crop was only treated with hilling, and 30 days after planting (DAP). Irrigation was suspended at 80 DAP because most of the plants were already at an advanced stage of maturation, with yellowish foliage and aerial part drying.

A thermohygrometer-data logger (AK172) was installed in each trial. Daily weather data on temperature and humidity (minimum, maximum, average) were collected. The emergence of potato plants was evaluated 12, 19, 24 and 30 days after planting (DAP) the tubers. A total of five plants were sampled at each replicate to determine the number of stems at 35 and 50 DAP.

The crop was harvest at 94 DAP. The number of tubers per plant, number of commercial tubers per plant, number of non-commercial tubers per plant, mass of commercial tubers $\left(\mathrm{kg}\right.$ plant $\left.^{-1}\right)$, mass of non-commercial tubers $\left(\mathrm{kg}\right.$ plant $\left.\mathrm{t}^{-1}\right)$, total productivity (ton $\mathrm{ha}^{-1}$ ), commercial productivity (ton $\mathrm{ha}^{-1}$ ), noncommercial productivity (ton $\mathrm{ha}^{-1}$ ), and diameter of tubers without defects $(\mathrm{mm})$ were determined.

The percentage of defects (severe, mild and variable) associated to dry rot, wet rot, nematode incidence, secondary growth, rhizoctonia, skinning, greening, growth cracks, "pin" borer (Diabrotica sp worm damage), termite damage, sprouting and cutting were quantified in tuber characterization. Tubers with severe defects and computed as noncommercial were those that presented any level of defect associated with dry rot, wet rot, nematode, deep damage and cut.

Statistical analyses of experiments followed, PIMENTEL GOMES (2009). Mean residual squares of each experiment were checked. Treatment effect was determined by an F test, and "genotypes" factor means were compared using a Tukey test. Correlation between physiological variables and production was analyzed. Multivariate methods were also employed using the Principal Component Analysis with a correlation matrix.

\section{RESULTS AND DISCUSSION}

Emergence: Plants of all genotypes emerged at 12 days after planting, in both crop environments. The genotype 'BRSIPR Bel' stood out in the protected environment on precocity, with $94 \%$ emergence (Figure 1). However, the same genotype presented the worst performance under open field conditions due to rotted tubers.

The emergence of potato plants stabilized at 24 DAP regardless of genotype and crop environment (Figure 1). The average emergence period for autumn plantings in subtropical regions, such as Rio Grande do Sul (Southern Brazil), are much longer, taking around 20 to 30 days from planting to emergence (ZANON et al., 2013). Thus, there was an early emergence of genotypes evaluated in tropical climate conditions. This early emergence is possibly associated with higher soil temperatures (Table 1), 


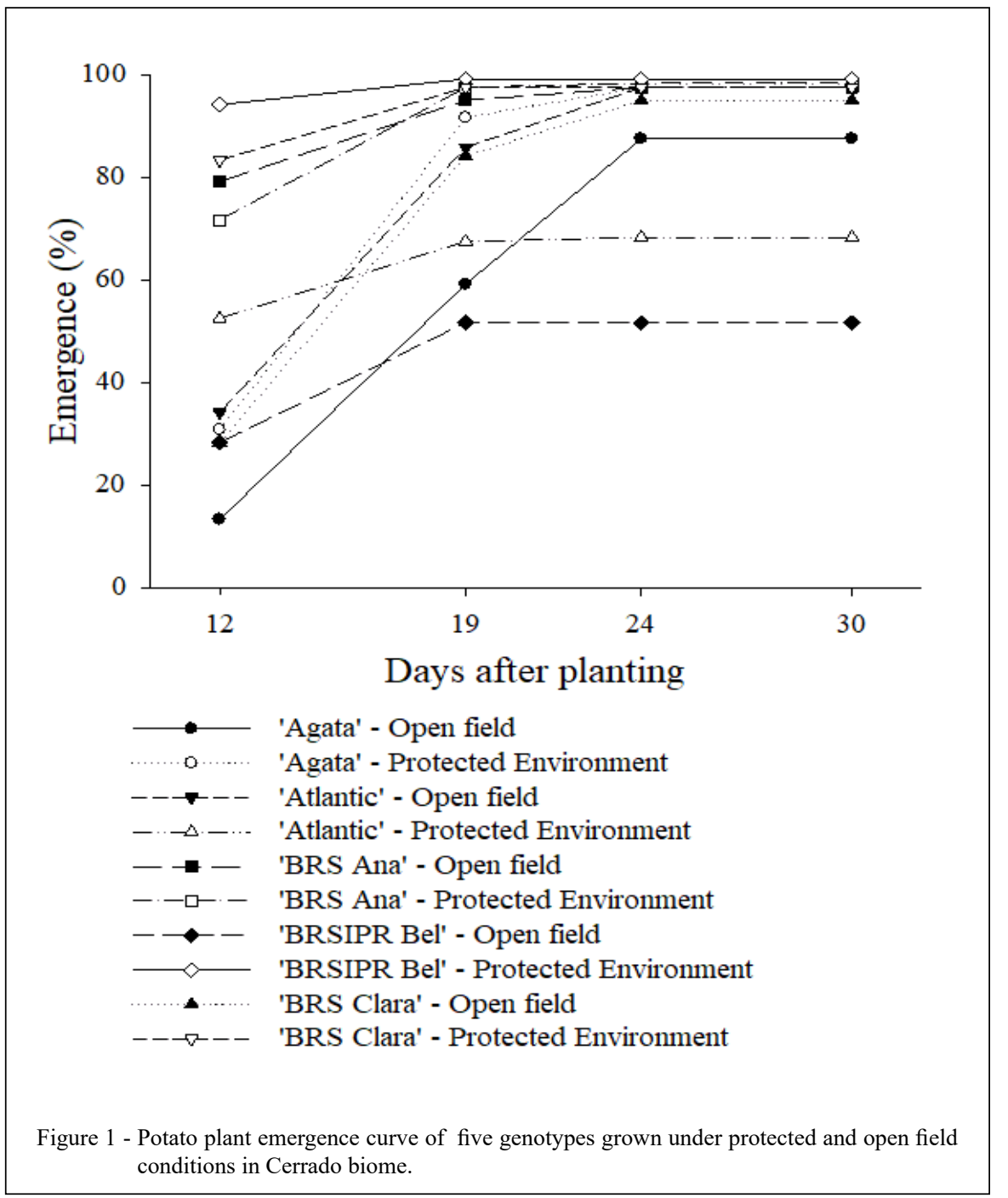

which are fundamental factors for the emergence of potato plants (LIANG et al., 2018).

Correlation - Emergence, Stems and Productivity: The number of stems in potato plants at 35 and 50 DAP was not affected by the environment of cultivation (Table 2). This characteristic is related mainly to the genotype, size and physiological age of the seed tuber (SOUZA, 2003).

The genotypes 'BRS Ana' and 'BRSIPR Bel' exhibited the highest numbers of stems in both periods evaluated (35 and 50 DAP; Table 2). The seed tubers of these genotypes had, upon planting, the physiological age of the normal bud stage (full sprouting vigor). This is the ideal planting stage for tubers with intermediate diameter $(30-50 \mathrm{~mm})$, as they provide higher yields. The number of stems is a key attribute for the population density of potato plants (IRITANI et al., 1983; LEMAGA \& CAESAR, 1990). Each stem is an independent plant. Therefore, the number and size of the tubers produced depends directly on the competition of these stems for light, nutrients and water (QUEIROZ et al., 2013 a).

The number of plant stems of the genotypes 'BRS Clara', 'Agata' and 'Atlantic' was low. The seed tubers used in planting had intermediate size (30-50 $\mathrm{mm})$ and physiological age of normal budding (full sprouting vigor) for genotype 'BRS Clara'. Therefore, a higher emission of stems was expected. However, the genotype is derived from crosses between 'White Lady' (mother) and 'Catucha' 
Table 1 - Mean, maximum, and minimum temperature and relative humidity measured weekly under protected and open environment during organic potato production in Cerrado biome.

\begin{tabular}{|c|c|c|c|c|c|c|}
\hline Weeks after planting & $\begin{array}{c}\text { Temp. } \\
\text { mean }\end{array}$ & $\begin{array}{c}\text { Temp. } \\
\text { maximum }\end{array}$ & $\begin{array}{l}\text { Temp. } \\
\text { minimum }\end{array}$ & $\begin{array}{c}\text { Humid. } \\
\text { mean }\end{array}$ & $\begin{array}{l}\text { Humid. } \\
\text { maximum }\end{array}$ & $\begin{array}{l}\text { Humid. } \\
\text { minimum }\end{array}$ \\
\hline Open Field & ${ }^{\circ} \mathrm{C}$ & ${ }^{\circ} \mathrm{C}$ & ${ }^{\circ} \mathrm{C}$ & $\%$ & $\%$ & $\%$ \\
\hline 3 & 24.93 & 36.60 & 17.45 & 74.72 & 97.65 & 43.40 \\
\hline 4 & 21.81 & 33.90 & 14.46 & 79.83 & 99.91 & 43.70 \\
\hline 5 & 23.24 & 38.77 & 14.74 & 73.77 & 99.77 & 32.26 \\
\hline 6 & 23.88 & 43.60 & 13.19 & 69.73 & 100.00 & 23.90 \\
\hline 7 & 23.13 & 39.63 & 13.44 & 71.16 & 99.64 & 28.79 \\
\hline 8 & 23.10 & 42.94 & 12.69 & 68.55 & 99.39 & 21.89 \\
\hline 9 & 23.07 & 37.84 & 13.87 & 70.58 & 99.04 & 31.41 \\
\hline 10 & 20.79 & 36.93 & 10.50 & 67.36 & 98.16 & 27.13 \\
\hline 11 & 22.95 & 41.73 & 11.83 & 64.46 & 97.64 & 21.80 \\
\hline 12 & 21.35 & 34.76 & 13.26 & 73.64 & 99.03 & 38.30 \\
\hline 13 & 22.37 & 40.74 & 11.67 & 62.63 & 97.07 & 22.10 \\
\hline 14 & 22.18 & 40.63 & 11.10 & 61.75 & 96.43 & 20.35 \\
\hline \multicolumn{7}{|c|}{ - } \\
\hline 3 & 25.38 & 33.30 & 19.10 & 73.36 & 94.35 & 48.05 \\
\hline 4 & 22.25 & 31.69 & 16.56 & 79.85 & 97.14 & 49.21 \\
\hline 5 & 23.28 & 33.60 & 16.57 & 75.94 & 97.63 & 42.07 \\
\hline 6 & 23.15 & 35.16 & 15.11 & 73.39 & 97.63 & 35.34 \\
\hline 7 & 22.94 & 34.56 & 15.27 & 74.70 & 98.24 & 38.26 \\
\hline 8 & 22.33 & 34.60 & 14.41 & 73.33 & 97.80 & 35.19 \\
\hline 9 & 22.89 & 33.70 & 15.63 & 74.17 & 97.73 & 39.47 \\
\hline 10 & 20.59 & 31.87 & 12.59 & 71.73 & 95.89 & 36.36 \\
\hline 11 & 21.94 & 34.14 & 13.59 & 70.11 & 96.34 & 32.49 \\
\hline 12 & 21.27 & 31.07 & 14.89 & 77.41 & 97.63 & 46.14 \\
\hline 13 & 21.96 & 33.53 & 13.74 & 66.48 & 92.99 & 31.77 \\
\hline 14 & 21.80 & 34.60 & 13.25 & 64.50 & 93.13 & 27.55 \\
\hline
\end{tabular}

(father) (PEREIRA et al. 2013), from Hungary (Pannon University of Agricultural Sciences) and Brazil (Epagri), respectively. Therefore, 'BRS Clara' may be a genotype more suited to subtropical climate conditions (PASSOS et al., 2017) due to a lower vigor in stem emission and low productivity in tropical climate (Table 2).

'Agata' and 'Atlantic' seed tubers were very small $(20-25 \mathrm{~mm})$ and had the physiological age of apical dominance and normal budding, respectively. However, tuber size seems to have exerted greater effect on the number of stems than on the physiological age. The smaller the tuber, the smaller the number of stems emitted (QUEIROZ et al., $2013 \mathrm{~b}$ ). Smaller tubers optimize population densities due to a reduced competition among plants and within a plant (among the stems) (ALLEN, 1978). Thus, greater productivity and economic returns are expected. However, such results were not observed with this study.
The 'Agata' and 'Atlantic' genotypes exhibited the worst performances in relation to total productivity (Table 2), even producing a higher number of tubers in relation to the amount of stems emitted ('Agata' - 1.90; 'Atlantic' - 2.13; 'BRS Ana' - 1.4; 'BRS IPR Bel' - 1.79; 'BRS Clara' 1.37). This is mainly due to two factors: low mass of the tubers produced and the spacing employed. As these genotypes emitted low amounts of stems, the final densities of stems were very low in relation to the other genotypes ('Agata' - 62,121.21 stems/ ha; 'Atlantic' - 44,545.45 stems/ha; 'BRS Ana' 180,909.09 stems/ha; 'BRS IPR Bel' 192,424.24 stems/ha; 'BRS Clara' 91,212.12 stems/ha). Therefore, the only way to compensate for this low number of stems and unit mass of tubers would be to thicken the planting. Commercially the optimal number of stems should be from 100,000 to 150,000 per hectare to obtain relevant yields (FILGUEIRA, 2007; NICK \& BORÉM, 2017). However, this is a

Ciência Rural, v.52, n.5, 2022. 
Table 2 - Stem number at 35 days after planting per plant (S35); stem number at 50 days after planting per plant (S50); Number of tubers per plant (NTub); Number of commercial tubers per plant (NCTub); Number of non-commercial tubers per plant (NNCTub); mass of commercial tubers - $\mathrm{kg}$ plant $^{-1}$ (MCTub); mass of non-commercial tubers - $\mathrm{kg}$ plant $^{-1}$ (MNCTub); total productivity ton $\mathrm{ha}^{-1}(\mathrm{TP})$; commercial productivity - ton ha ${ }^{-1}(\mathrm{CP})$; non-commercial productivity - ton ha ${ }^{-1}(\mathrm{NCP})$ and diameter (D) in mm of tubers without defects from potato genotypes produced in different environments (O.F. - Open field; P.E. - Protected environment) under organic management.

\begin{tabular}{|c|c|c|c|c|c|c|c|c|c|c|c|}
\hline \multirow[b]{2}{*}{ Variables } & \multicolumn{3}{|c|}{-------Environment (A)----- } & \multicolumn{6}{|c|}{ 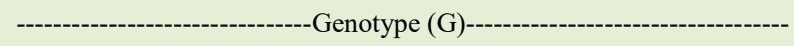 } & \multirow{2}{*}{$\begin{array}{c}(\mathrm{Ax} \mathrm{G}) \\
\begin{array}{c}\mathrm{F} \\
\text { test }\end{array}\end{array}$} & \multirow{2}{*}{$\begin{array}{l}- \\
\mathrm{CV} \\
(\%)\end{array}$} \\
\hline & O.F. & P.E. & $\begin{array}{c}\mathrm{F} \\
\text { test }\end{array}$ & 'Agata' & 'Atlantic' & $\begin{array}{l}\text { 'BRS } \\
\text { Ana' }\end{array}$ & $\begin{array}{c}\text { 'BRSIPR } \\
\text { Bel' }\end{array}$ & $\begin{array}{c}\text { 'BRS } \\
\text { Clara' }\end{array}$ & $\begin{array}{c}\mathrm{F} \\
\text { test }\end{array}$ & & \\
\hline S35 & 3.83 & 3.56 & $0.57 \mathrm{~ns}$ & $2.40 \mathrm{~b}$ & $1.40 \mathrm{~b}$ & $5.80 \mathrm{a}$ & $6.10 \mathrm{a}$ & $2.77 b$ & $28.32^{* *}$ & $0.18 \mathrm{~ns}$ & 30.5 \\
\hline S50 & 3.81 & 3.73 & $0.05 \mathrm{~ns}$ & $2.05 b$ & $1.47 \mathrm{~b}$ & $5.97 \mathrm{a}$ & $6.35 \mathrm{a}$ & $3.01 \mathrm{~b}$ & $29.76^{* *}$ & $0.40 \mathrm{~ns}$ & 30.9 \\
\hline Ntub & 5.62 & 6.76 & $5.85^{*}$ & $3.90 \mathrm{c}$ & $3.14 \mathrm{c}$ & $8.39 b$ & $11.39 \mathrm{a}$ & $4.14 c$ & $44.98^{* *}$ & $0.18 \mathrm{~ns}$ & 24.2 \\
\hline NCTub & 4.37 & 6.12 & $18.91^{* *}$ & $3.42 \mathrm{c}$ & $2.79 \mathrm{c}$ & $6.61 b$ & $9.93 \mathrm{a}$ & $3.44 \mathrm{c}$ & $44.77^{* *}$ & $0.95 \mathrm{~ns}$ & 24.3 \\
\hline NNCTub & 1.25 & 0.64 & $7.56^{*}$ & $0.47 \mathrm{bc}$ & $0.35 \mathrm{c}$ & $1.77 \mathrm{a}$ & $1.45 \mathrm{ab}$ & $0.69 b c$ & $6.48^{* *}$ & $2.33 \mathrm{~ns}$ & 73.4 \\
\hline MCTub & 0.15 & 0.26 & $30.33^{* *}$ & $0.08 \mathrm{c}$ & $0.10 \mathrm{bc}$ & $0.33 \mathrm{a}$ & $0.34 \mathrm{a}$ & $0.19 b$ & $28.07^{* *}$ & $4.22^{* *}$ & 30.6 \\
\hline MNCTub & 0.04 & 0.02 & $2.38 \mathrm{~ns}$ & $0.008 b$ & $0.01 \mathrm{~b}$ & $0.07 \mathrm{a}$ & $0.04 \mathrm{ab}$ & $0.05 \mathrm{ab}$ & $4.50^{* *}$ & $4.37^{* *}$ & 96.7 \\
\hline TP & 6.12 & 9.01 & $14.46^{* *}$ & $2.82 \mathrm{c}$ & $3.58 \mathrm{c}$ & $12.25 \mathrm{a}$ & $11.72 \mathrm{a}$ & $7.44 b$ & $26.91^{* *}$ & $3.27^{*}$ & 31.8 \\
\hline $\mathrm{CP}$ & 4.71 & 8.14 & $30.33^{* *}$ & $2.55 \mathrm{c}$ & $3.24 b c$ & $10.06 a$ & $10.38 \mathrm{a}$ & $5.90 \mathrm{~b}$ & $28.07^{* *}$ & $4.22^{* *}$ & 30.6 \\
\hline $\mathrm{NCP}$ & 1.40 & 0.86 & $2.38 \mathrm{~ns}$ & $0.27 \mathrm{~b}$ & $0.33 b$ & $2.19 \mathrm{a}$ & $1.33 \mathrm{ab}$ & $1.53 \mathrm{ab}$ & $4.50^{* *}$ & $4.37^{* *}$ & 96.7 \\
\hline $\mathrm{D}$ & 32.30 & 34.48 & $4.58^{*}$ & $29.15 b$ & $34.39 a$ & $34.68 \mathrm{a}$ & $33.72 \mathrm{ab}$ & $35.02 \mathrm{a}$ & $4.55^{* *}$ & $1.89 \mathrm{~ns}$ & 9.6 \\
\hline
\end{tabular}

${ }^{*}$ significant $(\mathrm{P}<0.05) ;{ }^{* *}$ significant $(\mathrm{P}<0.01)$; ns - non-significant $(\mathrm{P}>0.05)$.

Means followed by the same letter do not differ by Tukey's test $(\mathrm{P}>0.05)$.

reference for industrial production systems. It cannot be generalized to organic production systems.

It is essential to relate potato ecophysiology to the size of tubers and spacing used in planting in tropical climate conditions. Many recommendations are based on genotypes grown in temperate climate. Thus, further studies are suggested in tropical organic systems, with variations in the spacing and size of tubers in planting. The variation of these factors accompanied by a physiological evaluation of the plants will help in obtaining relevant inferences for producers and scientists.

Early emergence and number of stems (35 and 50 DAP) are positively correlated with total and commercial yield of potato plants (Table 3). This pattern is recognized as essential for potato production to achieve maximum productive potential, both in tropical and subtropical regions. Faster emergence and development of the plant culminates in a higher absorption of light energy in

Table 3 - Correlation matrix between emergence (E), stem per plant (S) and total productivity (TP), commercial productivity (CP) and non-commercial productivity (NCP) of potato genotypes produced under organic management, in Cerrado biome.

\begin{tabular}{|c|c|c|c|c|c|c|c|}
\hline & E-12 DAP & E - 30DAP & S - 35 DAP & S- 50 DAP & $\mathrm{TP}$ & $\mathrm{CP}$ & $\mathrm{NCP}$ \\
\hline E - 12 DAP & 1 & & & & & & \\
\hline E - 30 DAP & 0.380 & 1 & & & & & \\
\hline S - 35 DAP & 0.436 & -0.152 & 1 & & & & \\
\hline S - 50 DAP & 0.509 & -0.131 & $0.986^{*}$ & 1 & & & \\
\hline $\mathrm{TP}$ & $0.809^{*}$ & 0.108 & $0.811^{*}$ & $0.848^{*}$ & 1 & & \\
\hline $\mathrm{CP}$ & $0.798^{*}$ & 0.148 & $0.761^{*}$ & $0.788^{*}$ & $0.974^{*}$ & 1 & \\
\hline NCP & 0.409 & -0.098 & 0.556 & 0.612 & 0.553 & 0.351 & 1 \\
\hline
\end{tabular}

${ }^{*}$ significant $(\mathrm{P}<0.05)$. 
a short time, synchronizing the tuberization period and the maximum photosynthetic performance of the foliage (LEMAGA \& CAESAR, 1990). Therefore, it is important to take notice of the soil moisture conditions, luminous intensity, photoperiod, nutrients and phytosanitary conditions, in addition to factors related to seed tuber for stem emergence and emission (BOITEAU, 2010; ROSSI et al., 2011).

Number and diameter of tubers: The number and diameter of tubers were affected by the production environment (Table 2). Tubers from protected environment were higher number, greater mass and less defects than those obtained in the open field environment. The superior results obtained for the protected environment can be associated to lower maximum temperatures and higher relative humidity in the period of tuberization and tuber growth (Table 1).

Tuberization takes place from the fifth week to the seventh week after planting (SOUZA, 2003). This is a short period, that lasts from 10 to 15 days and is considered crucial for the formation of the tubers that will be harvested. RYKACZEWSKA (2013) suggests that the earlier the temperature stress, the more negative will be the impact on tuber growth and yield.

Plants in open field exhibited less vigorous growth than in the protected environment. The balance between photosynthesis and respiration is crucial for the growth of the aerial part, formation and filling of tubers (SOUZA, 2003). Therefore, plants provided more photoassimilates for the so-called maintenance respiration in open field. Maintenance respiration involves the restoration of membranes and active cellular transport, culminating in less reserve for the growth breath, which in turn is responsible for the formation and growth of new tissues and organs (TAIZ et al., 2017), and consequent tubercle production.

The genotype 'BRSIPR Bel' stood out among the others for producing the largest number of tubers per plant (Table 2) which was almost four times more than the recorded for 'Agata' and 'Atlantic'. PEREIRA et al. (2015) describe that this genotype exhibits high productive potential due to the large number of tubers per stem and low incidence of non-commercial tubers.

Tuber diameter ranged from 29 to $35 \mathrm{~mm}$ (Table 2). According to the Potato Classification System, adopted by Ceagesp (São Paulo), 'Agata' tubers would fall under category IV, and 'BRSIPR Bel', 'BRS Ana' and 'BRS Clara' tubers under category III (CÂMARA SETORIAL DE BATATA,
1999). Tubers considered marketable by such classification should be categorized as: I (>70 mm), II ( $>42 \mathrm{~mm}$ to $70 \mathrm{~mm})$ or III ( $>33 \mathrm{~mm}$ to $42 \mathrm{~mm})$. However, such classification system is mainly 'Agata' tubers obtained in conventional system. The use of this cultivar as the "standard" is due to the predominance of this genotype in Brazilian crops.

Consumers of organic tubers are milder about market requirements related to size, mass and diameter (RAGASSI et al., 2020). For this consumer other factors are more important, such as food safety and sustainability in production. Virtually all the production offered is commercialized, regardless of the biometry of the tubers, due to the very low supply (ROSSI et al., 2011). Thus, the current classification standards for potato tubers do not fully apply to Brazilian organic potato cultivation. Organic potato production focuses on using a greater genotype variation, and the consumers of organic value diversity.

Mass of tubers and productivity: The 'BRSIPR Bel' and 'BRS Ana' genotypes stood out for the greater number of commercial tubers produced and for the individual mass of commercial tubers, leading to a greater commercial productivity. The performance of these genotypes was higher under protected environment conditions (Table 4; Figure 2). Potato yield in organic system is lower in conventional system (ZARZYNSKA \& PIETRASZKO, 2015; RAGASSI et al., 2020). In Europe, the productivity in organic areas is about $75-80 \%$ of the conventional plantation areas. This lower production is associated with nutritional and phytosanitary factors (HAGMAN et al., 2009; ROSSI et al., 2011; PAWELZIK \& MOLLER, 2014; EL-SAYED et al., 2015; NECHWATAL \& ZELLNER, 2015; BUSNELLO, et al., 2019; WILSON et al., 2019).

Defects: No defect associated with rhizoctonia and "pin" borer was detected. Defects associated with nematodes and sprouted tubers occurred only in the protected environment (Table 5). The protected environment has a history of nematode presence, especially of Meloidogyne incognita (Kofoid \& White) Chitwood and M. javanica (Treub) Chitwood, and incidence of damage to tomato productivity. Tubers of all genotypes were affected, with higher incidence in 'BRS Ana' and 'BRSIPR Bel'. The tubers exhibited small protuberances (galls) that resemble a "popcorn". There were no symptoms, such as reduced growth, wilting or yellowing, in the aerial part. VIAENE (2014) reported that the presence of nematodes in production areas may be a major threat to the sustainability of potato crops and that the best route to management is genetic resistance. 
Table 4 - Environment and genotype interactions with mass of commercial tubers (MCTub); mass of non-commercial tubers (MNCTub); total productivity (TP); commercial productivity $(\mathrm{CP})$; non-commercial productivity $(\mathrm{NCP})$, during organic potato production in Cerrado biome.

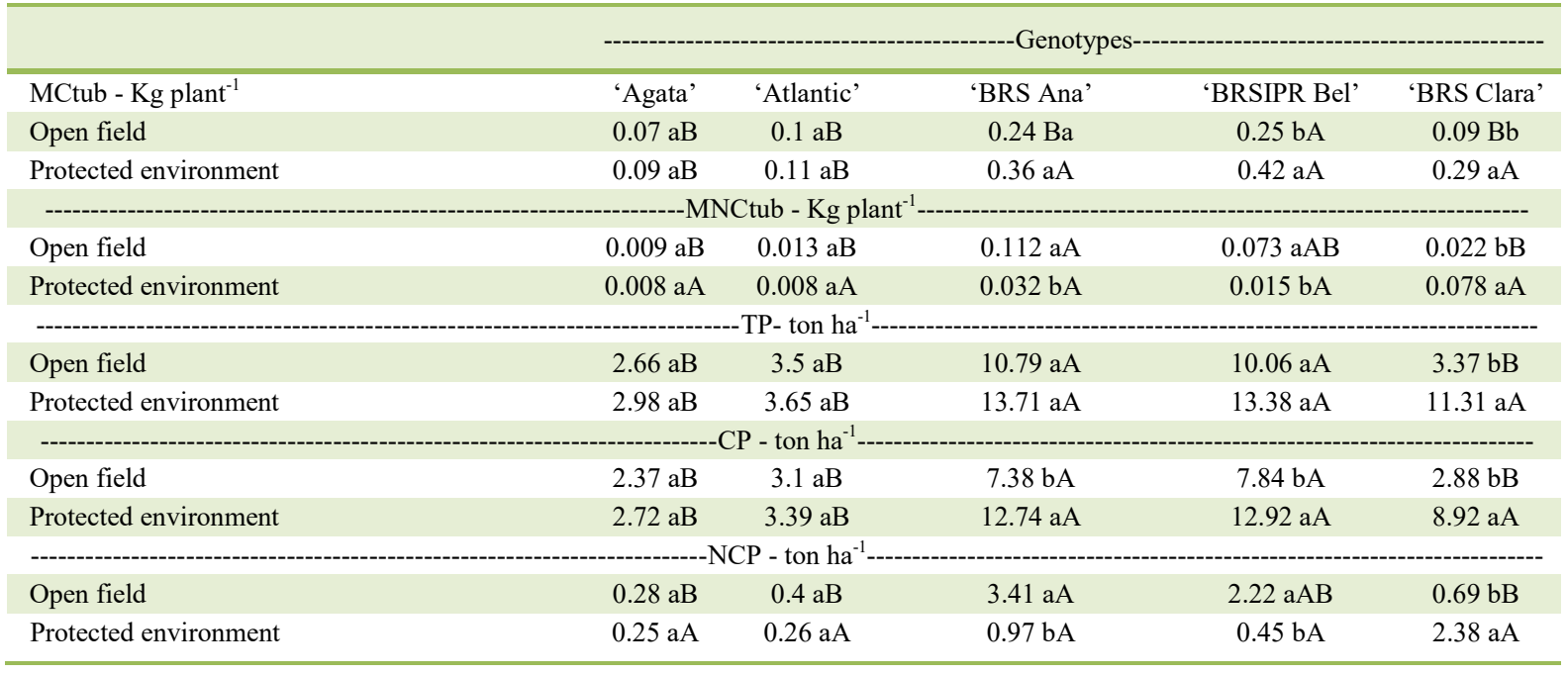

Means followed by the same lowercase letter in the column and upper case in the row do not differ by Tukey's test (P $>0.05)$

The genotype 'BRS Clara' exhibited the highest defect indexes associated with secondary growth and growth cracks. Growth cracks is considered a serious defect with several origins. Secondary growth is a consequence of physiological disorders associated with alternation of water supply associated with shutdown and resumption of growth. This result differs from that reported by PEREIRA et al. (2013) which do not describe the susceptibility of this genotype to physiological disorders.

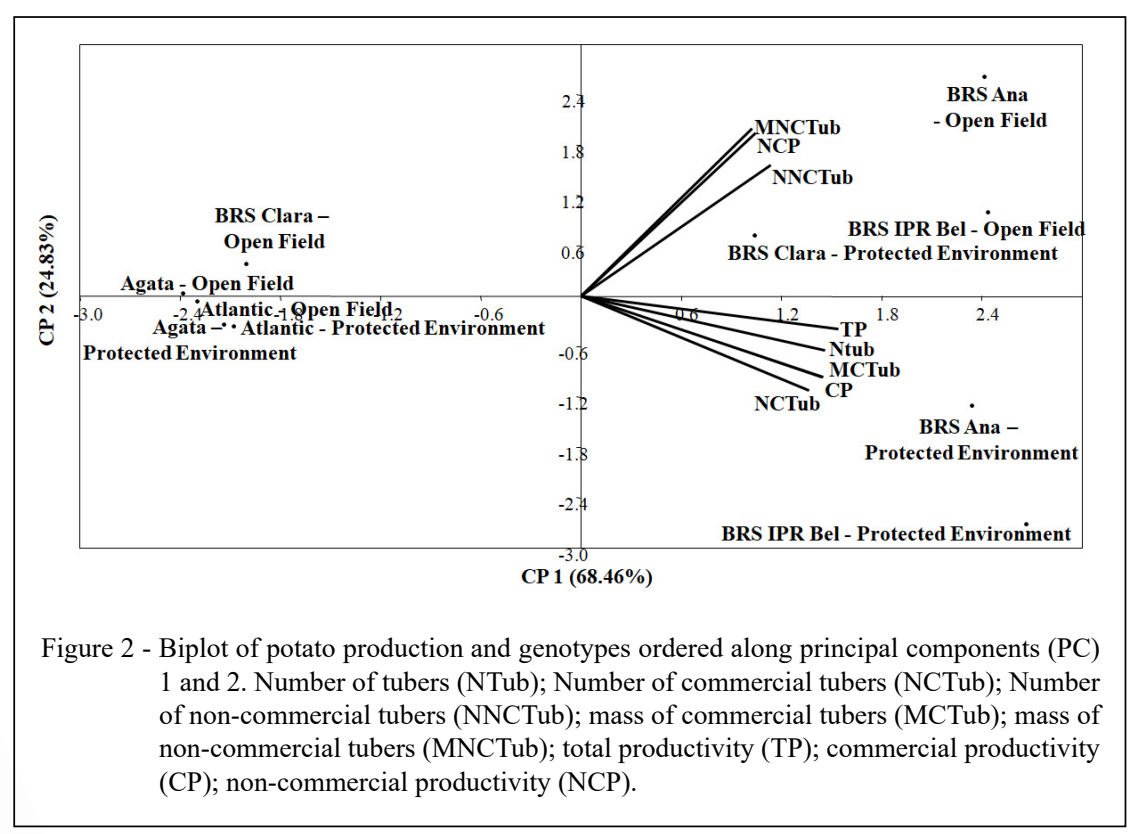

Ciência Rural, v.52, n.5, 2022. 
Table 5 - Effect of environment and genotype on the incidence of defects in tubers of potato grown under organic management, in Cerrado biome: dry rot (DR); wet rot (WR); nematoid (NE); secondary growth (SG); skinning (SK); greening (GR); growth cracks (GC); termite (TM); sprouting (SP) and cutting (CT).

\begin{tabular}{|c|c|c|c|c|c|c|c|c|c|c|}
\hline Treatments & $\begin{array}{l}\text { DR } \\
(\%)\end{array}$ & $\begin{array}{l}\text { WR } \\
(\%)\end{array}$ & $\begin{array}{l}\mathrm{NE} \\
(\%)\end{array}$ & $\begin{array}{l}\text { SG } \\
(\%)\end{array}$ & $\begin{array}{l}\text { SK } \\
(\%)\end{array}$ & $\begin{array}{l}\text { GR } \\
(\%)\end{array}$ & $\begin{array}{l}\text { GC } \\
(\%)\end{array}$ & $\begin{array}{l}\text { TM } \\
(\%)\end{array}$ & $\begin{array}{l}\text { SP } \\
(\%)\end{array}$ & $\begin{array}{l}\text { CT } \\
(\%)\end{array}$ \\
\hline \multicolumn{11}{|c|}{---------------------------------------------------------------------'Environment (A)------------------------------------------------------------------------ } \\
\hline Open field & 4.73 & 2.32 & 0.00 & 0.005 & 2.16 & 11.46 & 4.36 & 12.75 & 0.00 & 7.16 \\
\hline $\begin{array}{l}\text { Protected } \\
\text { environment }\end{array}$ & 1.43 & 1.35 & 13.56 & 0.003 & 1.11 & 7.78 & 2.50 & 16.02 & 0.20 & 3.78 \\
\hline F Test & $3.50 \mathrm{~ns}$ & $1.39 \mathrm{~ns}$ & $95.75^{* *}$ & $0.55 \mathrm{~ns}$ & $0.52 \mathrm{~ns}$ & $5.01^{*}$ & $2.34 \mathrm{~ns}$ & $0.86 \mathrm{~ns}$ & $3.19 \mathrm{~ns}$ & $2.75 \mathrm{~ns}$ \\
\hline \multicolumn{11}{|c|}{ 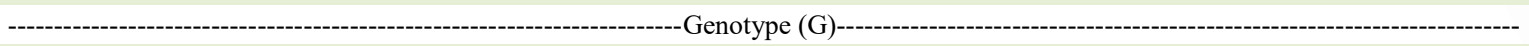 } \\
\hline 'Agata' & 0.99 & 1.10 & $0.79 \mathrm{~b}$ & $0.001 \mathrm{~b}$ & 1.21 & $2.44 \mathrm{~b}$ & $0.95 \mathrm{~b}$ & 18.22 & 0.47 & 5.83 \\
\hline 'Atlantic' & 2.44 & 0.52 & $2.44 \mathrm{~b}$ & $0.000 \mathrm{~b}$ & 3.50 & $9.95 \mathrm{~b}$ & $1.04 \mathrm{~b}$ & 14.68 & 0.00 & 4.82 \\
\hline 'BRS Ana' & 7.63 & 2.43 & $13.71 \mathrm{a}$ & $0.004 \mathrm{ab}$ & 0.02 & $18.61 \mathrm{a}$ & $2.73 \mathrm{~b}$ & 10.25 & 0.00 & 5.63 \\
\hline ‘BRSIPR Bel' & 2.39 & 1.13 & $12.15 \mathrm{a}$ & $0.001 \mathrm{~b}$ & 2.13 & $9.42 \mathrm{~b}$ & $2.76 \mathrm{~b}$ & 10.55 & 0.03 & 6.14 \\
\hline ‘BRS Clara’' & 1.94 & 4.00 & $4.79 \mathrm{~b}$ & $0.016 \mathrm{a}$ & 1.31 & $7.70 \mathrm{~b}$ & $9.67 \mathrm{a}$ & 18.23 & 0.00 & 4.95 \\
\hline F Test & $1.75 \mathrm{~ns}$ & $2.29 \mathrm{~ns}$ & $14.11^{* *}$ & $4.91^{* *}$ & $0.64 \mathrm{~ns}$ & $10.09^{* *}$ & $7.04^{* *}$ & $0.99 \mathrm{~ns}$ & $2.65 \mathrm{~ns}$ & $0.06 \mathrm{~ns}$ \\
\hline F Test $(A \times G)$ & $0.30 \mathrm{~ns}$ & $0.72 \mathrm{~ns}$ & $14.11^{* *}$ & $0.41 \mathrm{~ns}$ & $0.87 \mathrm{~ns}$ & $9.25^{* *}$ & $1.71 \mathrm{~ns}$ & $0.44 \mathrm{~ns}$ & $2.65 \mathrm{~ns}$ & $1.41 \mathrm{~ns}$ \\
\hline
\end{tabular}

${ }^{*}$ significant $(\mathrm{P}<0.05) ;{ }^{* *}$ significant $(\mathrm{P}<0.01)$; ns - non-significant $(\mathrm{P}>0.05)$.

Means followed by the same letter do not differ by Tukey's test $(\mathrm{P}>0.05)$

The incidence of greening was higher in the open field environment and in tubers of the genotype 'BRS Ana'. Greening derives from the direct effect of the light on tubers converting amyloplasts into chloroplasts and from the biosynthesis of glycoalkaloids ( $\alpha$-solanine and $\alpha$-chaconine) (CONOVER \& PRIKE, 1987; REEVES, 1988). The light incidence on the ground is greater in the open field environment, even with hilling. In addition, the greater spacing between the planting lines, compared to the conventional pattern, may have favored the direct incidence in the tubers.

The color of the 'BRS Ana' genotype tubers was reddish / red. Sensitivity to greening is considered poor to medium (PEREIRA et al., 2010). Thus, a higher frequency of heaping is suggested in the management of this genotype to avoid the direct incidence of light in the tubers.

\section{CONCLUSION}

The protected environment is the most suitable for organic potato production under small areas and the evaluated conditions. The genotypes 'BRSIPR Bel' and 'BRS Ana' have a high productive potential under organic system conditions.

\section{ACKNOWLEDGEMENTS}

This study was financed in part by the Coordenação de Aperfeiçoamento de Pessoal de Nível Superior - Brasil (CAPES) - Finance Code 001

\section{DECLARATION OF CONFLICT OF INTEREST}

The authors declare no conflict of interest. The founding sponsors had no role in the design of the study; in the collection, analyses, or interpretation of data; in the writing of the manuscript, and in the decision to publish the results.

\section{AUTHORS' CONTRIBUTIONS}

The authors contributed equally to the manuscript.

\section{REFERENCES}

ALLEN, E. J. Plant density. In: HARRIS, P. M. The potato crop: the scientific basis for improvement. London: Chapman \& Hall, 1978. p.278-326.

BOITEAU, G. Insect pest control on potato: harmonization of alternative and conventional control methods. American Journal of Potato Research, v.87, p.412-419, 2010. Available from: $<$ http://dx.doi.org/10.1007/s12230-010-9158-z>. Accessed: Feb. 03, 2021. doi: 10.1007/s12230-010-9158-z.

BUSNELLO, F. J. et al. Potato genotypes reaction to early blight and late blight in organic cultivation. Ciência Rural, 
v.49, e20180469, 2019. Available from: <http://dx.doi. org/10.1590/0103-8478cr20180469>. Accessed: Feb. 03, 2021. doi: $10.1590 / 0103-8478 \mathrm{cr} 20180469$.

CÂMARA SETORIAL DA BATATA. Normas de classificação da batata (Solanum tuberosum L.) para o Programa Brasileiro para a melhoria dos padrões comerciais e embalagens de hortigranjeiros. 1999. Available from: <http://www.ceagesp. gov.br/wp-content/uploads/2015/07/batata.pdf $>$. Accessed: Feb. 02, 2021.

ÇALISKAN, M. E. et al. Comparison of aeroponics and Conventional Potato Mini Tuber Production Systems at Different Plant Densities. Potato Research , 2020. Available from: $<$ https:// doi.org/10.1007/s11540-020-09463-z.>. Accessed: Feb. 03, 2021. doi: 10.1007/s11540-020-09463-z.

CEPEA-ESALQ. Especial batata: gestão sustentável. Hortifruti Brasil, v.19, n. 205, p.12-28, 2020. Available from: <https:// www.hfbrasil.org.br/br/revista/acessar/completo/bataticultura-secapitaliza-em-plena-pandemia.aspx> . Accessed: May. 20, 2021

CONOVER , J. C. AND PRIKE, J. A. Plastid and nuclear DNA in potato tuber tissue during greening. Journal of Experimental Botany, v.38, p.1219-1227,1987. Available from: <http://dx.doi org/10.1093/jxb/38.7.1219>. Accessed: Feb. 03, 2021. doi: $10.1093 / \mathrm{jxb} / 38.7 .1219$

FAOSTAT.Faostat. Database resultes. Accessed February 01, 2021. Available from: <http://faostat.fao.org.html $>$. Accessed: Feb. 02, 2021

FILGUEIRA, F. A. R. Novo manual de olericultura: Agrotecnologia moderna na produção e comercialização de hortaliças. 3.ed. Viçosa: Ed. UFV, 2007.

EL-SAYED, S. F. et al. Impact of bio and organic fertilizers on potato yield, quality and tuber weight loss after harvest. Potato Research, v.58, p.67-81, 2015. Available from: <https://doi. org/10.1007/s11540-014-9272-2>. Accessed: Feb. 03, 2021. doi: $10.1007 / \mathrm{s} 11540-014-9272-2$.

GREENWAY, G. A. et al. An analysis of organic potato demand in the U.S. American Journal of Potato Research, v.88, p.184189,2011. Available from: <https://doi.org/10.1007/s12230-0109180-1>. Accessed: Feb. 03, 2021. doi: 10.1007/s12230-010$9180-1$.

HAGMAN, J. E. et al. Cultivation practices and potato cultivars suitable for organic potato production. Potato Research, v.52, p.319-330,2009. Available from: $<$ https://doi.org/10.1007/s11540009-9128-3>. Accessed: Feb. 03, 2021. doi: 10.1007/s11540-0099128-3.

IRITANI, W. M. et al. Relationships between stem number, tuber set and yield of russet burbank potatoes. American Journal of Potato Research, v.60, p.423-431,1983. Available from: $<$ https:// doi.org/10.1007/BF02877248>. Accessed: Feb. 03, 2021. doi: 10.1007/BF02877248

LEMAGA, B. AND CAESAR, K. Relationships between numbers of main stems and yield components of potato (Solanum tuberosum L. cv. Erntestolz) as influenced by different daylengths. Potato Research, v.33, p.257-267,1990. Available from: <http:// doi.org/10.1007/BF02358455>. Accessed: Feb. 03, 2021. doi: $10.1007 / \mathrm{BF} 02358455$
LIANG, S. et al. Improvements of emergence and tuber yield of potato in a seasonal spring arid region using plastic film mulching only on the ridge. Field Crops Research, v.223, p.57-65,2018. Available from: <http://doi.org/10.1016/j.fcr.2018.03.012>. Accessed: Feb. 03, 2021. doi: 10.1016/j.fcr.2018.03.012.

PASSOS, S. et al . Yield of organic potato cultivars in the subtropical region of Brazil Horticultura Brasileira, v.35, n.4, p.628-633, 2017. Available from: <https://doi.org/10.1590/s0102053620170424>. Accessed: Feb. 03, 2021. doi: 10.1590/s0102053620170424

PAWELZIK, E. AND MOLLER, K. Sustainable potato production worldwide: the challenge to assess conventional and organic production systems. Potato Research, v.57, p.273-290, 2014 Available from: <https://doi.org/10.1007/s11540-015-9288-2>. Accessed: Feb. 03, 2021. doi: 10.1007/s11540-015-9288-2.

PEREIRA, A. S. et al. BRS Ana: A dual purpose potato cultivar. Horticultura Brasileira, v.28, p.500-505, 2010. Available from: $<$ https://doi.org/10.1590/S0102-05362010000400021>. Accessed: Feb. 03, 2021. doi: 10.1590/S0102-05362010000400021.

PEREIRA, A. S. et al. BRSIPR Bel: A chip-processing potato cultivar with tubers of good appearance. Horticultura Brasileira, v.33, p.135-139,2015. Available from: <https://doi.org/10.1590/ S0102-053620150000100022>. Accessed: Feb.03, 2021. doi: 10.1590/S0102-053620150000100022.

PEREIRA, A. S. et al. BRS Clara: a late-blight-resistant fresh market potato cultivar. Horticultura Brasileira, v.31, p.664668,2013. Available from: <https://doi.org/10.1590/S010205362013000400026> Accessed: Feb. 03, 2021 doi: 10.1590/ S0102-05362013000400026.

PIMENTEL GOMES, F. Curso de estatística experimental. Piracicaba: FEALQ, 2009.

NECHWATAL, J. AND ZELLNER, M. Potential suitability of various leaf treatment products as copper substitutes for the control of late blight (Phytophthora infestans) in organic potato farming. Potato Research, v.58, p.261-276, 2015. Available from: <https:// doi.org/10.1007/s11540-015-9302-8>. Accessed: Feb.03, 2021. doi: $10.1007 / \mathrm{s} 11540-015-9302-8$.

NICK, C.; BORÉM, A. Batata: do plantio à colheita. 1.ed. Viçosa: Ed. UFV, 2017.

QUEIROZ, L. R. M. et al. NPK fertilization and potato tuber seed size on growth, yield and profitability of potato plants. Horticultura Brasileira, v.31, p.119-127, 2013a. Available from: $<$ https://doi.org/10.1590/S0102-05362013000100019>. Accessed: Feb.03, 2021. doi: 10.1590/S0102-05362013000100019.

QUEIROZ, L. R. M. et al. Tuber, seed size and spacing on potato yield under field conditions. Comunicata Scientiae, v.4, p.308$315,2013 b$

RAGASSI, C. F. et al. Performance of advanced potato genotypes in organic and conventional production systems. Horticultura Brasileira, v.38, p.53-57, 2020. Available from: <https://doi. org/10.1590/s0102-053620200108>. Accessed: Feb.03, 2021. doi: $10.1590 / \mathrm{s} 0102-053620200108$.

REEVES, A. L. Varietal differences in potato tuber greening. American Potato Journal, v.65, p.651-658,1988. Available from: 
$<$ https://doi.org/10.1007/BF02854833>. Accessed: Feb.03, 2021. doi: $10.1007 / \mathrm{BF} 02854833$.

ROSSI, F. et al. Potato cultivars for organic production systems. Horticultura Brasileira, v.29, p.372-376,2011. Available from: $<$ https://doi.org/10.1590/S0102-05362011000300019>. Accessed: Feb. 03, 2021. doi: 10.1590/S0102-05362011000300019.

RYKACZEWSKA, K. The impact of high temperature during growing season on potato cultivars with different response to environmental stresses. American Journal of Plant Science, v.4 p.2386-2393,2013. Available from: <http://dx.doi.org/10.4236/ ajps.2013.412295>. Accessed: Feb.03, 2021. doi: 10.4236/ ajps.2013.412295

SOUZA, Z. S. Ecofisiologia. In: PEREIRA, A. S.; DANIELS, J. A cultura da batata na região Sul do Brasil. Brasília: Embrapa Informação Tecnológica, 2003. p.80-99.

TAIZ, L. et al. Fisiologia e desenvolvimento vegetal. 6.ed. Porto Alegre: Artmed, 2017.
VIAENE, N. Nematodes: an increasing threat for the potato crop in Europe? Potato Research, v.57, p.335-338, 2014. Available from: $<$ https://doi.org/10.1007/s11540-015-9284-6>. Accessed: Feb. 03,2021. doi: 10.1007/s11540-015-9284-6.

ZANON, A. J. et al. Plant development and tuber yield in the potato in a subtropical climate. Ciência Agronômica, v.44, p.858-868,2013. Available from: <https://doi.org/10.1590/S180666902013000400024>. Accessed: Feb. 03,2021. doi: 10.1590/ S1806-66902013000400024.

ZARZYNSKA, K., PIETRASZKO, M. Influence of climatic conditions on development and yield of potato plants growing under organic and conventional systems in Poland. American Journal of Potato Research, v.92, p.511-517,2015. Available from: <https://doi.org/10.1007/s12230-015-9465-5>. Accessed: Feb. 03,2021. doi: 10.1007/s12230-015-9465-5.

WILSON, R. et al. Cover crops prove effective at increasing soil nitrogen for organic potato production. California Agriculture, v.73, p.79-89,2019. Available from: <https://doi.org/10.3733/ ca.2019a0005 > . Accessed: Feb. 03,2021. doi: 10.3733/ca.2019a0005. 